\title{
PENDIDIKAN KARAKTER INDIGENOUS DALAM PERSPEKTIF AL-QUR'AN
}

\author{
Yudianto Achmad \\ Institut PTIQ Jakarta \\ Email: yudiachmad@yahoo.com
}

\begin{abstract}
This study aims to reveal the formulation of concepts and models for the implementation of indigenous character education in the Al-Qur'an perspective for students in premarital, prenatal, and golden ages. The interpretation method of al-Maudhu'i and a qualitative approach are used in this dissertation, in order to produce descriptive data through observation of the letters and verses of the Qur'an, and the science associated with indigenous character education in the perspective of the Qur'an. The results of this study, among others, revealed; 1). Formulation of concepts and models for the implementation of indigenous character education in the perspective of the Qur'an; 2). Religious indigenous character, love for the homeland, intellectuality from the Prophets (Prophet Adam, Prophet Ibrahim, Prophet Muhammad); 3). Character of religious indigenous, love of homeland, taqwā intellectuality (kindness); 4). Religious indigenous character, homeland love, intellectuality fujūr (evil); 5). Formulation of the "TADZKIROH PLUS" implementation model in premarital, prenatal, and golden ages. The conclusion of this study, among others, is that in the perspective of science and the Qur'an, humans from birth have two types of indigenous characters in pairs and are mutually opposite, namely the character of goodness (taqwâ) and character of ugliness (fujûr). Actualization and development through character education that maximizes the character of goodness (taqwâ) and minimizes the character of badness (fujûr).
\end{abstract}

Keywords: Indigenous, Character, Taqwa, Fujūr. 


\begin{abstract}
ABSTRAK
Penelitian ini bertujuan mengungkapkan perumusan konsep dan model implementasi pendidikan karakter indigenous dalam perspektif Al-Qur'an untuk peserta didik di masa usia pranikah, prenatal, serta golden age. Metode tafsir al-Maudhu'i dan pendekatan kualitatif digunakan dalam penelitian ini, agar menghasilkan data deskriptif melalui observasi terhadap surat dan ayat Al-Qur'an, serta sains yang terkait dengan pendidikan karakter indigenous dalam perspektif Al-Qur'an. Hasil dari penelitian ini, antara lain mengungkapkan; 1). Perumusan konsep dan model implementasi pendidikan karakter indigenous dalam perspektif Al-Qur'an; 2). Karakter indigenous religius, cinta tanah air, intelektualitas dari para Nabi (Nabi Adam, Nabi Ibrahim, Nabi Muhammad); 3). Karakter indigenous religius, cinta tanah air, intelektualitas taqwā (kebaikan); 4). Karakter indigenous religius, cinta tanah air, intelektualitas fujūr (keburukan); 5). Perumusan model implementasi "TADZKIROH PLUS" di masa usia pranikah, prenatal, serta golden age. Kesimpulan dari penelitian ini, antara lain bahwa dalam perspektif sains dan Al-Qur'an, manusia dari sejak dilahirkan memiliki 2 jenis karakter indigenous yang berpasangan dan bersifat saling berlawanan, yakni karakter kebaikan (taqwâ) dan karakter keburukan (fujûr). Aktualisasi dan pengembangannya melalui pendidikan karakter yang memaksimalkan karakter kebaikan (taqwâ) dan meminimalkan karakter keburukan (fujûr).
\end{abstract}

Kata Kunci: Indigenous, Karakter, Taqwā, Fujūr. 


\section{PENDAHULUAN}

\section{Latar Belakang Masalah}

Marak terjadinya berbagai peristiwa dekadensi karakter di Indonesia hingga saat ini, mengakibatkan bermunculan kondisi "darurat" yang sangat meresahkan masyarakat, karena terjadi disetiap lapisan dalam aspek-aspek kehidupan masyarakat. Sedangkan kondisi "darurat" yang dimaksud antara lain seperti; "Darurat" Korupsi; "Darurat" Narkoba; ${ }^{2}$ "Darurat" Perilaku, Pelecehan dan Kekerasan Seksual; "Darurat LGBT (Lesbian Gay Biseksual, Transgender)"; "Darurat Kriminalitas"; kondisi "darurat" lainnya yang disebabkan oleh terjadinya berbagai peristiwa dekadensi karakter. Dari berbagai peristiwa dekadensi karakter yang menimbulkan banyak kondisi "darurat" tersebut, diantaranya dilakukan oleh mereka yang termasuk dalam kategori usia anak dan remaja (usia "generasi penerus bangsa" $)$, apabila hal tersebut disandingkan dengan indikator dari Lickona, ${ }^{7}$ akan terlihat bahwa di Indonesia diduga telah

\footnotetext{
${ }^{1}$ Wapresri, "Korupsi di Indonesia sudah dalam keadaan lampu merah darurat", dalam http://www.wapresri.go.id/kebijakan-bukan-bagian-perkara/, diakses pada tanggal 27/11/2016.

${ }^{2}$ Ahmad Romadoni, "Mengapa Indonesia Darurat Narkoba?", dalam http://news.liputan6. com/read/2233219/mengapa-indonesia-darurat-narko ba, diakses pada tanggal 27/11/2016.

3“Pemerkosaan Berjamaah: Indonesia Darurat Kekerasan Seksual?", http://www.dw.com/ id/pemerkosaan-berjamaah-indonesia-darurat-kekerasanseksual/a-9233807, diakses pada tanggal 27/11/2016.

${ }^{4}$ M. Taufiq, Ninis Chairunissa (ed.), "DPR dan MUI Sepakat LGBT Dipidana dalam RKUHP", dalam https://nasional.tempo.co/read/1057953/dprdan-mui-sepakat-lgbt-di pidana-dalam-rkuhp, di akses pada 29/11/2016.

${ }^{5} \mathrm{Di}$ Indonesia memiliki kecenderungan menaiknya tindak kejahatan setiap tahunnya, yakni setiap 1 menit 29 detik terjadi kejahatan kriminal di Indonesia. Badan Pusat Statistik, Statistik Kriminal 2016, Jakarta: BPS, 2016; 20.

${ }^{6}$ Anak dan remaja termasuk dalam kategori "Generasi Penerus Bangsa", diantaranya dalam Undang-Undang No. 35 Tahun 2014, pada bagian "Menimbang" di butir "c": "...bahwa anak sebagai tunas, potensi, dan generasi muda penerus cita-cita perjuangan bangsa memiliki peran strategis...". Davit Setyawan, "Undang-Undang Republik Indonesia Nomor 35 Tahun 2014 Tentang Perubahan Atas Undang-Undang Nomor 23 Tahun 2002 Tentang Perlindungan Anak", dalam http://www. kpai.go.id/hukum/undang-undang-republik-indonesia-nomor-35-tahun-2014tentang-perubahan-atas-undang-undang-nomor-23-tahun-2002-tentangperlindungan-anak, diakses pada tanggal 29/11/2016.

${ }^{7}$ Indikator yang dapat menunjukkan ciri-ciri tentang adanya kegagalan dalam pendidikan karakter bagi anak dan remaja dalam suatu bangsa Thomas Lickona, penerjemah Juma Abdu Wamaungo, Educating for
} 
terjadi kegagalan dalam pendidikan karakter, sehingga berbagai peristiwa dekadensi karakter tersebut dapat menjadi salah satu penyebab munculnya isu adanya kegagalan pendidikan karakter di Indonesia. Selain itu sistem dan pelaksanaan pendidikan di Indonesia antara tahun 2001 hingga tahun 2017 dinilai buruk oleh berbagai lembaga-lembaga Internasional berdasarkan hasil riset yang dilakukan oleh mereka. Penilaian buruk dimaksud datangnya antara lain berasal dari lembaga-lembaga seperti dari; Political and Economic Risk Consultancy (PERC); ${ }^{8}$ United Nations Educational Scientific and Cultural Organization (UNESCO) $;{ }^{9}$ The Economist Intelligence Unit (EIU). ${ }^{10}$ Secara umum semua hasil penilaian antara tahun 2001 hingga tahun 2017 dari lembaga-lembaga dimaksud menyatakan bahwa

Character:Mendidik Untuk Membentuk Karakter. Jakarta: Bumi Aksara, 2012; 20-31.

${ }^{8}$ Library.ohiou, "Penilaian PERC Terhadap Sistem Pendidikan Indonesia", dalam https://www.library.ohiou.edu/indopubs/2001/09/04/ 0124.html, diakses tanggal 01/11/2016.

${ }^{9}$ Indeks pembangunan pendidikan atau Education Development Index (EDI) Indonesia adalah sebesar 0,934. Nilai tersebut menempatkan Indonesia di posisi ke-69 dari 127 negara di dunia. EDI dikatakan tinggi jika mencapai 0,95 sampai dengan 1. Kategori medium berada di atas 0,80, sedangkan kategori rendah di bawah 0,80. United Nations Educational Scientific and Cultural Organization (UNESCO), Education For All (EFA) Global Monitoring Report 2011: The Hidden Crisis, Armed Conflict and Education, France: UNESCO, 2011; 264.

${ }^{10}$ The EIU adalah sebuah badan yang terkemuka di dunia untuk riset ekonomi dan bisnis, peramalan dan analisis. pada tahun 2012 mempublikasi hasil laporan survei terhadap peringkat pencapaian hasil pendidikan di negaranegara seluruh dunia. Dalam laporan hasil survei tersebut, dari 40 negara didunia yang disurvei mengenai cognitive skills and educational attainment (ketrampilan kognitif dan pencapaian pendidikan) Indonesia masuk ke dalam group 5 yang menunjukan nilai kondisi Indonesia di bawah standar deviasi rata-rata pencapaian pendidikan, serta menduduki urutan terakhir atau urutan ke-40 dunia, sebagai perbandingan dengan Singapura, negara tetangga Indonesia dalam lingkup ASEAN yang menempati group 2 yang menunjukkan nilai di atas standar deviasi rata-rata pencapaian pendidikan dan memiliki urutan ke-5 dunia. The Economist Intelligence Unit, The Learning Curve: Lesson In Country Performance In Education: 2012 Report, (London: Pearson Plc, 2012), h. 40. Kemudian The EIU kembali mengeluarkan laporan hasil survei yang sejenis sebelumnya di tahun 2014. Hasil survei yang dikeluarkan menunjukkan bahwa setelah 2 tahun berjalan, Indonesia masih tetap berada dalam group 5 dan tetap menduduki urutan terakhir atau urutan ke-40 dunia, namun sebaliknya Singapura meningkat naik peringkatnya dari urutan ke-5 menjadi urutan ke-3 dunia. The Economist Intelligence Unit, The Learning Curve: Lesson In Country Performance In Education: 2014 Report, London: Pearson Plc, 2014; 20-21. 
Indonesia memiliki kondisi buruk dibawah standar ukuran yang ditetapkan oleh masing-masing lembaga-lembaga tersebut dalam pelaksanaan sistem pendidikan. Hal tersebut menyebabkan semakin memperkuat bergulirnya isu tentang adanya kegagalan pendidikan karakter di tengah-tengah masyarakat Indonesia.

Dikeluarkan kebijakan berupa Undang-Undang No. 20 tahun 2003 tentang Sistem Pendidikan Nasional, terlihat sebagai upaya pemerintah Indonesia mengatasi hal yang terkait dengan penilaian-penilaian dimaksud. Upaya pemerintah Indonesia berlanjut dengan menetapkan berbagai kebijakan yang terkait dengan sistem pendidikan termasuk pendidikan karakter, diantaranya dengan mengeluarkan kebijakan untuk menguatkan pendidikan karakter di Indonesia melalui Peraturan Presiden No. 87 tahun 2017 tentang Penguatan Pendidikan Karakter. Kebijakan pemerintah Indonesia tersebut menunjukkan bahwa pelaksanaan sistem pendidikan yang menyeluruh di Indonesia, termasuk didalamnya melibatkan mengenai pendidikan karakter, memegang peranan yang sangat penting dalam rangka membentuk, membangun karakter suatu bangsa, serta memiliki keterkaitan yang sangat erat dalam rangka pelaksanaan secara utuh dan menyeluruh dalam upaya proses "nation character building". ${ }^{11}$

Pendidikan karakter atau dikenal dengan pendidikan akhlak dalam perspektif Islam, juga dipandang sangat penting dan merupakan bagian tak terpisahkan dari konsep pendidikan dalam Islam secara keseluruhan di dalam menjalani kehidupan dunia dengan berdasarkan petunjuk dari firman-firman Allah dalam Al-Qur'an, serta ajaran dari Nabi Muhammad sebagai Rasul-Nya. Selain itu dalam perspektif Islam, berkaitan dengan pentingnya karakter manusia dan proses aktualisasi, serta pengembangan karakter melalui pendidikan karakter, dijelaskan dalam Al-Qur'an bahwa manusia lahir ke dunia sedikitpun tidak

${ }^{11}$ Pada waktu bangsa Indonesia memproklamasikan kemerdekaan Indonesia pada tanggal 17 Agustus 1945, The Founding Father menyadari bahwa ada tiga tantangan besar yang harus dihadapi, yakni: "Pertama; Mendirikan Negara yang Bersatu dan Berdaulat, Kedua; Membangun Bangsa, Ketiga; Membangun karakter." Ketiga hal tersebut secara jelas tampak dalam konsep Negara Bangsa (Nation-State) dan Nation Character Building. Muchlas Samani dan Hariyanto, Konsep dan Model Pendidikan Karakter, Bandung: Remaja Rosdakarya, 2012; 1-2. 
memiliki pengetahuan, tetapi diberikan potensi indera, akal, serta hati oleh Allah. ${ }^{12}$

Kondisi dimaksud dijelaskan dalam tafsir tematik bahwa potensi-potensi fitrah manusia pemberian Allah yang dibawa dari sejak lahir tersebut, dapat teraktualisasikan ketika manusia memanfaatkan modalitasnya secara maksimal dalam berinteraksi dengan lingkungan alam maupun sosial sebagai salah satu wujud rasa bersyukur kepada Allah. ${ }^{13}$

Potensi-potensi alamiah manusia pemberian dari Allah dimaksud, Al-Qur'an menjelaskan antara lain seperti jasmani atau raga tubuh manusia, ${ }^{14}$ serta potensi alamiah yang lainnya, termasuk jiwa atau nafs ${ }^{15}$ manusia yang ditengarai sebagai pembentuk karakter manusia. Hal tersebut seperti yang diuraikan Ibnu Sina, Al-Farabi, Al-Kindi sebagaimana dikutip Syah Reza yang menjelaskan bahwa "نفس" - "nafs"/jiwa adalah merupakan elemen utama dari pembentuk karakter manusia. ${ }^{16}$

Dari penjelasan dimaksud, maka terungkap bahwa karakter manusia adalah termasuk diantara potensi alamiah manusia pemberian Allah dari sejak dilahirkan, serta potensi

${ }^{12} \mathrm{Al}-\mathrm{Qur}$ 'an surat Al-Nahl[16] ayat 78, arti; "Dan Allah mengeluarkan kamu dari perut ibumu dalam keadaan tidak mengetahui sesuatupun, dan Dia memberi kamu pendengaran, penglihatan dan hati, agar kamu bersyukur".

${ }^{13}$ Lajnah Pentashihan Mushaf Al-Qur'an, Tafsir Al-Qur'an Tematik: Pendidikan, Pembangunan Karakter, Dan Pengembangan Sumber Daya Manusia - Seri 4, Jakarta: Badan Litbang dan Diklat Kementrian Agama RI, (Jakarta: 2010), h. 3.

${ }^{14}$ Diantaranya dalam Al-Qur'an surat Al-Mu'minûn[23] ayat 12-14, artinya: "Dan sesungguhnya Kami telah menciptakan manusia dari suatu saripati (berasal) dari tanah. Kemudian Kami jadikan saripati itu air mani (yang disimpan) dalam tempat yang kokoh (rahim). Kemudian air mani itu Kami jadikan segumpal darah, lalu segumpal darah itu Kami jadikan segumpal daging, dan segumpal daging itu Kami jadikan tulang belulang, lalu tulang belulang itu Kami bungkus dengan daging. Kemudian Kami jadikan dia makhluk yang (berbentuk) lain. Maka Maha sucilah Allah, Pencipta Yang Paling Baik".

${ }^{15}$ Diantaranya dalam Al-Qur'an surat Al-Syams[91] ayat 7, artinya: "Dan demi jiwa penyempurnaannya (ciptaan-Nya)". Selain itu dalam Al-Qur'an surat Yusuf[12] ayat 53, artinya; "Dan aku tidak membebaskan diriku (dari kesalahan), karena sesungguhnya nafs -jiwa-itu selalu menyuruh kepada kejahatan, kecuali nafs -jiwa- yang diberi rahmat oleh Tuhanku. Sesungguhnya Tuhanku Maha Pengampun lagi Maha Penyayang".

${ }^{16}$ Kata "Nafs" dalam bahasa Arab "النفس" dan dalam Inggris "Soul/Spirit" secara harafiah berarti "Jiwa". Ibnu Sina, Al-Farabi, Al-Kindi mengisyaratkan "nafs" sebagai elemen pembentuk karakter seseorang. Syah Reza, Konsep Nafs Menurut Ibnu Sina, dalam Jurnal KALIMAH, Vol. 12, No. 2, UNIDA, Gontor, September 2014; 266. 
alamiah ini dapat mengalami perubahan karena adanya suatu pengaruh.

Sementara itu dalam sains di bidang Psychology, diantaranya pada sub bidang Indigenous Psychology ${ }^{17}$ yang merupakan pengembangan dari cabang ilmu Psikologi, menyiratkan jika manusia memiliki karakter indigenous atau karakter dasar, asli, alamiah yang terbagi menjadi dua bagian dan bersifat ganda atau berpasangan, serta saling berlawanan, yakni; 1). Karakter Indigenous Kebaikan; 2). Karakter Indigenous Keburukan. Kedua karakter indigenous tersebut dapat terpengaruh oleh kondisi ke indigenous-an manusia dalam konteks: keluarga, budaya asal, sosial, ekologis, historis, filosofis, dan lainnya yang terkait dengan karakter manusia. Sedangkan konsekuensi atas pemilihan kedua jenis karakter alamiah dari sejak dilahirkan atau karakter indigenous dimaksud, memiliki "reward" dan "punishment" yang didasarkan pada nilai etika, moral dan aturan yang berlaku sesuai tempat, situasi dan kondisi. ${ }^{18}$

\footnotetext{
${ }^{17}$ Kata "Indigenous" berarti memiliki arti; Native (Asli); Produce (diproduksi), growing (tumbuh), or living (atau hidup), naturally in a country or climate (secara alami di suatu negara atau iklim); Not exotic (tidak eksotis); Not Imported (tidak diimpor). Artikata, "Definisi "Indigenous"”, dalam http://www.artikata.com/arti-95081-indigenous.html, diakses tanggal 02/12/2016.

${ }^{18}$ Kuang-Kuo Hwang mengatakan bahwa Indigenous Psychology muncul kali pertama di kawasan Asia pada sekitar tahun 1970. Pada waktu itu, banyak Psikolog di negara-negara diluar wilayah "Barat" yang mengadopsi teori-teori, konsep-konsep dan metodologi penelitian Psikologi yang berkembang di wilayah "Barat" untuk diaplikasikan di wilayah "Timur" tempat asal mereka. Namun, setelah diterapkan, ditemukan adanya ketidaksesuaian antara konsep "Barat" dengan Psikologi masyarakat "Timur". Selain itu konsep dan metodologi penelitian Psikologi Barat juga tidak mampu memecahkan permasalahan yang tengah dihadapi oleh masyarakat yang berada diwilayah "Timur" dalam kehidupan sehari-harinya, sehingga muncul dan berkembanglah Indigenous Psychology sebagai jawaban atas keprihatinan para Psikolog "non-barat". Bahasa sederhana untuk menjelaskan hal dimaksud adalah; Indigenous Psychology kemungkinan besar muncul sebagai ketidakpuasan atas konsep Psikologi masyarakat "Barat" dalam menjawab permasalahan Psikologi masyarakat "Timur". Kuang-Kuo Hwang. The epistemological goal of indigenous psychology: The perspective of constructive realism. In B. N. Setiadi, A. Supratiknya, W. J. Lonner, \& Y. H. Poortinga (Eds.). Ongoing themes in psychology and culture (Online Ed.), Melbourne, FL: International Association for Cross-Cultural Psychology, 2004; 1 .
} 
Terkait dengan hal tersebut, Al-Qur'an diantaranya mengungkapkan bahwa manusia diberikan potensi alamiah bawaan sejak lahir dari Allah, yakni suatu potensi karakter alamiah manusia potensi alamiah nafs sebagai elemen pembentuk karakter manusia yang berupa dua jenis karakter yang bersifat ganda/berpasangan dan saling berlawanan satu sama lain, yakni manusia tidak hanya diberikan potensi karakter alamiah yang bersifat kebaikan atau bersifat taqwâ saja, tetapi manusia juga diberikan potensi karakter alamiah yang bersifat keburukan atau bersifat fujûr. ${ }^{19}$

Oleh karena itu di dalam melakukan pendidikan karakter manusia, perlu memahami karakter indigenousnya, yakni memperhatikan sisi kebaikannya (taqwâ) dengan upaya mengembangkan secara optimal dan upaya meminimalkan atau bahkan mengeliminir, serta menghilangkan sisi keburukannya (fujûr). Semua uraian tersebut, menjadi dasar kuat dan layak bagi penulis untuk melakukan penelitian tentang penyusunan konsep dan model implementasi pendidikan karakter dimasa pranikah, prenatal, serta golden age yang memperhatikan kondisi keindigenous-an karakter manusia dalam perspektif Al-Qur'an yang berjudul: "Pendidikan Karakter Indigenous dalam Perspektif AlQur'an"

\section{Rumusan Masalah}

1. Bagaimana wacana perdebatan tentang; Pengertian indigenous dalam berbagai perspektif?; Pengertian karakter dan karakter indigenous?; Pendidikan karakter indigenous

\footnotetext{
${ }^{19} \mathrm{Al}$-Qur'an dalam surat Yusuf[12] ayat 53, artinya; "Dan aku tidak membebaskan diriku (dari kesalahan), karena sesungguhnya nafs -jiwa-itu selalu menyuruh kepada kejahatan, kecuali nafs -jiwa- yang diberi rahmat oleh Tuhanku. Sesungguhnya Tuhanku Maha Pengampun lagi Maha Penyayang". Kemudian dalam Al-Qur'an surat Al-Syams[91] ayat 5-8, arti: "Dan demi langit serta pembinaannya, dan bumi serta penghamparannya, dan jiwa serta penyempurnaannya (ciptaannya), maka Allah mengilhamkan kepada jiwa itu (jalan) kefasikan dan ketakwaannya." Penafsiran Sayid Quthub sebagaimana dikutip oleh Quraish Shihab terhadap surat Al-Syams[91] ayat 8 tersebut yang mengatakan bahwa: "Manusia adalah mahluk dwi dimensi dalam tabiatnya, potensinya dan dalam kecenderungan arahnya. Ini karena ciri penciptaannya sebagai mahluk yang tercipta dari tanah dan hembusan rûh Illahi, menjadikannya memiliki potensi yang sama dalam kebajikan dan keburukan, petunjuk dan kesesatan, dia mampu mengarahkan dirinya menuju kebaikan (taqwâhâ) atau keburukan (fujûrohâ) dalam kadar yang sama". Muhammad Quraish Shihab, Tafsir al-Mishbah, Pesan Kesan dan Keserasian Al-Qur'an - Vol.5, Jakarta: Lentera Hati, 2005, cet. III; 299.
} 
dalam lingkup: pengertian, paradigma, prinsip dan indikatornya?; Pengembangan karakter indigenous dimasa pranikah, di masa prenatal, serta di masa golden age?, serta Bagaimana analisis urgensi pendidikan karakter indigenous terkait upaya mengatasi berbagai dekadensi karakter hingga kini dan relasi antara pendidikan karakter indigenous dengan berbagai sains dan kondisi terkini, seperti dengan; Ilmu Naqliyah?; Ilmu 'Aqliyyah?; Ilmu 'Amaliyyah?.

2. Bagaimana bentuk konsep pendidikan karakter indigenous dalam perspektif Al-Qur'an?, serta bentuk model implementasi dari pendidikan karakter indigenous dalam perspektif Al-Qur'an untuk masa pranikah, masa prenatal, serta masa golden age?.

\section{Tujuan dan Kegunaan}

Tujuan dari penelitian ini adalah untuk mengungkapkan perumusan bentuk model implementasi dari Pendidikan Karakter Indigenous dalam Perspektif Al-Qur'an di masa pranikah, di masa prenatal dan di masa golden age. Sedangkan kegunaan dari penelitian ini adalah;

a. Memperkuat basis argumen terhadap pendidikan karakter indigenous dalam perspektif Al-Qur'an dalam upaya ikut serta berpartisipasi sumbang saran dalam aspek pendidikan karakter,

b. Mengungkapkan kajian ilmiah tentang bentuk konsep dan model implementasi Pendidikan Karakter Indigenous dalam Perspektif Al-Qur'an untuk masa pranikah, prenatal dan golden age,

c. Melengkapi khasanah keilmuan tafsir tentang konsep dan model Implementasi Pendidikan Karakter Indigenous dalam Perspektif Al-Qur'an.

\section{Kajian Pustaka}

Karya-karya ilmiah yang dikaji sebagai pendukung dalam penelitian ini, antara lain adalah:

1. Otong Surasman dalam penelitiannya yang berjudul “Karakter Manusia Dalam Al-Qur'an: Studi Tentang Kisah Nabi Ibrahim" membahas tentang karakter manusia yang terlihat mirip dengan karakter indigenous manusia dalam perspektif sains, yakni seperti diuraikan Thomas Lickona sebagaimana dikutip oleh Otong yang mengatakan bahwa: "Perilaku-perilaku menyimpang yang setiap hari 
membombardir kita - kekerasan, ketamakan, korupsi, ketidaksopanan, penyalahgunaan obat terlarang, asusila seksual, dan etika kerja yang buruk - mempunyai inti yang sama: tiadanya karakter yang baik...". Lebih lanjut dijelaskan oleh Otong bahwa Lickona juga menguraikan adanya 10 karakter kebajikan manusia, Selain itu terungkap juga karakter-karakter manusia dalam Al-Qur'an dalam berbagai surat dan ayatnya, antara lain yang terkandung dalam karakter Nabi Ibrahim. Dari kedua karakter yang diungkap Otong tersebut kemudian dibandingkan. Hasil dari perbandingan tersebut, dikatakan oleh Otong bahwa karakter dari Thomas Lickona tidaklah cukup untuk memperbaiki kondisi manusia agar tidak melakukan dekadensi karakter, namun 36 karakter Nabi Ibrahim yang digali dari surat dan ayat dalam Al-Qur'an sangatlah layak untuk diikuti dan diteladani oleh manusia dalam berperilaku di kehidupan kesehariannya. ${ }^{20}$

2. Ahmad Sulhan dalam penelitiannya "Manajemen Pendidikan Karakter dalam Mewujudkan Mutu Lulusan (Studi Multi Kasus di MA Dakwah Islamiyah Putri Kediri Lombok Barat dan SMA Negeri 2 Mataram)". membahas suatu bentuk karakter yang mirip dengan sebagaian dari karakter indigenous dalam pembahasan penelitian yang disusun penulis, yakni; 1). Karakter yang disebut dengan Akademik Excellent, terdiri dari karakter: Kejujuran, Kedisiplinan, Tanggung Jawab, Komunikatif, Kontrol Diri; 2). Karakter yang disebut Religius Awareness, terdiri dari karakter: Religius, Keikhlasan, Keteladanan, Mencintai Kebaikan. Penelitian Ahmad Sulhan juga memakai referensi dari Thomas Lickona dalam mendukung menyusun konstruksi teori pembahasan karakternya, yakni karakter: Moral Knowing, Moral Feeling, Moral Action dengan pendekatan keteladanan dan pendekatan sistem. Konsep pendidikan karakter yang disusun Ahmad Sulhan dalam penelitiannya mengusung model integratif yang disebut dengan model sistemik integratif, yakni model: Habitualisasi/pembiasaan, Personifikasi, Role Model Keteladanan yang terintegrasi dengan program ekstrakurikuler, intra dan ko-kurikuler dan pembentukan lingkungan (bi'ah), sehingga dengan model

${ }^{20}$ Otong Surasman, Karakter Manusia Dalam Al-Qur'an: Studi Tentang Kisah Nabi Ibrahim AS., Disertasi, Jakarta: Institut PTIQ Jakarta, 2015; 12. 
pendidikan karakter seperti dimaksud, diharapkan dapat menghasilkan lulusan yang bermutu. Sedangkan temuan dari penelitian ini, disebut oleh Ahmad Sulhan sebagai "Model Manajemen Pendidikan Karakter Sistemik Integratif berbasis personifikasi, role model dan habitualisasi". ${ }^{21}$

3. Danah Zohar dan Ian Marshall dalam bukunya yang berjudul "SQ: Spiritual Intelligence-The Ultimate Intelligence" yang diterjemahkan sebagai: "SQ, Memanfaatkan Kecerdasan Spiritual Dalam Berpikir Integralistik dan Holistik untuk Memaknai Kehidupan". Mereka mengatakan bahwa manusia saat ini hidup dalam budaya yang kehilangan pemahaman terhadap nilai-nilai dasar kehidupan atau disebut budaya "bodoh spiritual", budaya dimaksud memiliki ciri-ciri antara lain: materialistis, egois, tidak bermakna dan tidak punya komitmen. Sehingga terungkap jika manusia tidak mau memanfaatkan dan mengembangkan SQ-nya, maka cenderung memiliki karakter yang berlawanan dengan manusia yang mau memanfaatkan dan mengembangkan SQnya tersebut. ${ }^{22}$

4. Abu Ali al-Husein ibn Abdullah ibn al-Hasan ibn Ali Ibnu Sina lebih dikenal dengan Ibnu Sina dan di "barat" dikenal dengan Avicena, adalah ilmuwan Islam yang banyak menghasilkan karya-karya dalam berbagai bidang sains. Ibnu Sina sebagaimana dikutip oleh Syah Reza menjelaskan tentang nafs manusia bahwa nafs merupakan unsur awal kesempurnaan manusia (kamâl al-awwal li jism), sedangkan jasad merupakan unsur yang kedua bagi kesempurnaan manusia. Nafs yang didefinisikan Ibnu Sina dalam buku karyanya "Al-Syifầ'; al-Tabî'iyyah" adalah ruh memiliki potensi 'Aql yang terbagi menjadi; Nafs Natiqah/Insâniyyah (jiwa rasional manusia); Nafs Hayawâniyyah (jiwa hewani dalam diri manusia); Nafs Nabâtiyyah (jiwa nabati dalam diri manusia). ${ }^{23}$ Dari ketiga hal tersebut yang merupakan potensi

${ }^{21}$ Ahmad Sulhan, Manajemen Pendidikan Karakter dalam Mewujudkan Mutu Lulusan (Studi Multi Kasus di MA Dakwah Islamiyah Putri Kediri Lombok Barat dan SMA Negeri 2 Mataram), Disertasi, Malang: Universitas Islam Negeri Maulana Malik Ibrahim, 2015; viii.

${ }^{22}$ Danah Zohar dan Ian Marshal, SQ, Memanfaatkan Kecerdasan Spiritual dalam Berpikir Integralistik dan Holistik untuk Memaknai Kehidupan”, Bandung: Mizan, Cet.V., 2002;14-20.

${ }^{23}$ Nafs Natiqah/Insâniyyah adalah merupakan proses dalam memenuhi kebutuhan untuk melakukan segala aktifitas menurut pertimbangan dan kesimpulan dari aspek; pikiran dan persepsi manusia. Nafs Hayawâniyyah 
meninggikan derajat manusia dibanding mahluk lainnya adalah nafs natiqah, sekaligus menyiratkan bahwa jika nafs natiqah tidak difungsikan secara maksimal, maka manusia kemungkinan akan "bergerak" mengikuti nafs hayawâniyyah dan atau mengikuti nafs nabâtiyyah. ${ }^{24}$

5. Terkait dengan konsep pendidikan karakter indigenous yang dibahas dalam penelitian ini, Islam telah menjelaskan tentang konsep pendidikan prenatal yang didahului dengan konsep pendidikan masa pranikah, hal itu diuraikan oleh Ibnu Qayyim al-Jauziyyah $(691-751$ H) dalam kitab Tuhfatul Maudûd bi Ahkâmil Maulûd. ${ }^{25}$

6. Hal yang sama juga terdapat dalam buku karya Abdullah Nashih 'Ulwan: Tarbiyatul 'Aulâd fil Islâm, buku ini menguraikan tentang pendidikan karakter anak, dimulai dari persiapan pernikahan, menyiapkan kelahiran, tanggung jawab pendidikan anak, metode dan sarana pendidikan anak, kaidah asasi pendidikan anak. Semua itu ditujukan untuk anak dari sejak lahir, usia dini, golden age, baligh $^{26}$

7. Thomas Lickona, yang di Indonesia buku-buku-nya seolah telah menjadi "kutub" utama sebagai referensi bagi penyusunan konsep maupun implementasi pendidikan karakter. Lickona menguraikan tentang memberikan proses pendidikan yang mengajarkan rasa hormat dan bertanggung jawab kepada peserta didik melalui pendidikan nilai-nilai moral yang membentuk sebuah karakter bagi peserta didik secara general. ${ }^{27}$

adalah merupakan proses dalam memenuhi kebutuhan menurut hawa nafsu. Sedangkan Nafs Nabâtiyyah adalah merupakan proses dalam memenuhi kebutuhan menurut aspek; reproduksi, perkembangan tubuh, makanan. Syah Reza, Konsep Nafs Menurut Ibnu Sina, dalam Jurnal KALIMAH, Vol. 12, No. 2, UNIDA Gontor, September 2014; 271.

${ }^{24}$ Syah Reza, Konsep Nafs Menurut Ibnu Sina, dalam Jurnal KALIMAH, Vol. 12, No. 2, UNIDA Gontor, September 2014; 264-270.

${ }^{25}$ Ibnu Qayyim al-Jauziyyah, terj. Harianto, Tuhfatul Maudûd bi Ahkâmil Maulûd: Hanya Untukmu Anakku - Panduan Lengkap Pendidikan Anak Sejak Dalam Kandungan Hingga Dewasa, (Kairo: Dâr Ibnu Affan, cet. I, 1423H/2003M), Jakarta: Pustaka Imam Asy-Syafi'i, 2016.

${ }^{26}$ Abdullah Nashih 'Ulwan, penerjemah: Arif Rahman Hakim, Tarbiyatul 'Aulâd fil Islâm: Pendidikan Anak Dalam Islam, Solo: Al-Andalus, 2015, cet.1.

${ }^{27}$ Thomas Lickona, penerjemah: Juma Abdu Wamaungo, Uyu Wahyudin, dkk. (ed.), Educating for Character:How Our Schools Can Teach Respect and Responsibility (Mendidik Untuk Membentuk Karakter: Bagaimana Sekolah 


\section{Kerangka Teori}

Kerangka teori penelitian ini dapat dilihat penggambarannya sebagai berikut:

Gambar I.

\section{Kerangka Teori Penelitian}

\begin{tabular}{|c|c|c|}
\hline \multicolumn{3}{|c|}{$\begin{array}{c}\text { KONSEP DAN MODEL IMPLEMENTASI } \\
\text { PENDIDIKAN KARAKTER INDIGENOUS DALAM PERSPEKTIF AL-QUR'AN }\end{array}$} \\
\hline \multicolumn{3}{|c|}{ DUKUNGAN METODE HAPTONOMY, TAKSONOMI PENDIDIKAN BLOOM } \\
\hline $\begin{array}{l}\text { KARAKTER INDIGENOUS MANUSIA; } \\
\text { 1). KARAKTER INDIGENOUS KEBAIKAN; } \\
\text { 2). KARAKTER INDIGENOUS KEBURUKAN. }\end{array}$ & & $\begin{array}{l}\text { KARAKTER ALAMIAH MANUSIA; } \\
\text { 1). KARAKTER KEBAIKAN (TAQWĀ); } \\
\text { 2). KARAKTER KEBURUKAN (FUJŪR). }\end{array}$ \\
\hline $\begin{array}{l}\text { INDIGENOUS PSYCHOLOGY MENYIRATKAN BAHWA } \\
\text { MANUSIA MEMILIKI KARAKTER ALAMIAH DARI SEJAK } \\
\text { DILAHIRKAN ATAU KARAKTER INDIGENOUS YANG TERDIRI } \\
\text { DARI KEBAIKAN DAN KEBURUKAN. KARAKTER TERSEBUT } \\
\text { DAPAT TERPENGARUH OLEH KONDISI KE-INDIGENOUS- } \\
\text { ANNYA DALAM KONTEKS: KELUARGA, BUDAYA ASAL, } \\
\text { SOSIAL, EKOLOGIS, HISTORIS, FILOSOFIS, DAN YANG } \\
\text { LAINNYA. }\end{array}$ & $\begin{array}{l}\text { I } \\
\mathbf{1} \\
\mathbf{1} \\
\mathbf{1} \\
\mathbf{1} \\
\mathbf{1} \\
\mathbf{1}\end{array}$ & $\begin{array}{l}\text { MANUSIA DIKARUNIAI POTENSI AL-FITRAH BAWAAN DARI } \\
\text { SEJAK LAHIR YANG SAMA UNTUK SEMUA MANUSIA DAN } \\
\text { TIDAK DAPAT BERUBAH (QS. 30/30), NAMUN MANUSIA } \\
\text { JUGA DIKARUNIAI POTENSI ALAMIAH DARI SEJAK LAHIR } \\
\text { YANG DAPAT MENGALAMI PERUBAHAN KARENA ADANYA } \\
\text { SUATU PENGARUH, ANTARA LAIN SEPERTI; JASMANI (QS. } \\
\text { 23/12-14), DAN NAFS (QS.; } 91 / 7,12 / 53,39 / 42 \text { ). NAFS } \\
\text { SEBAGAI PEMBENTUK KARAKTER. NAFS YANG } \\
\text { BERPASANGAN DAN SALING BERLAWANAN, YAKNI; }\end{array}$ \\
\hline $\begin{array}{l}\text { PSIKOLOGI UMUM DAN PSIKOLOGI KEPRIBADIAN, SERTA } \\
\text { PSIKOLOGI EKSPERIMEN MENJELASKAN BAHWA MANUSIA } \\
\text { SEJAK DILAHIRKAN MEMILIKI KEPRIBADIAN ATAU } \\
\text { KARAKTER YANG TERDIRI DARI: KEBAIKAN DAN }\end{array}$ & $\begin{array}{l}\text { I } \\
\text { I } \\
\text { I } \\
\text { I }\end{array}$ & $\begin{array}{l}\text { UNTUK DIPILIH MANUSIA DENGAN IRINGAN UIIAN DAN } \\
\text { GODAAN (QS.; 21/35, 67/1-2, 15/39-40), SERTA ADANYA } \\
\text { "REWARD" \& "PUNISHMENT" TERHADAP PILIHAN } \\
\text { KEDUANYA (QS.; 91/9-10, 99/7-8). }\end{array}$ \\
\hline $\begin{array}{l}\text { KEBURUKAN. DALAM TEORI PSIKOLOGI PERKEMBANGAN } \\
\text { HIDUP MANUSIA: BAHWA KARAKTER MANUSIA } \\
\text { DIPENGARUHI OLEH PERKEMBANGAN HIDUP MANUSIA. }\end{array}$ & $\begin{array}{l}\text { I } \\
\text { I } \\
\text { I }\end{array}$ & $\begin{array}{l}\text { AL-QUR'AN PETUNJUK DAN SUMBER SEGALA HAL BAGI } \\
\text { MANUSIA DIANTARANYA PADA SURAT DAN AYAT; } 20 / 123 \text {. } \\
124 ; 3 / 138 ; 2 / 2 ; 17 / 9 ; 16 / 98 ; 3 / 132 ; 4 / 80 ; 64 / 12 .\end{array}$ \\
\hline $\begin{array}{r}\text { PENDUKUNG UTAMA: AL-QUR'AN DAN HADITS BERKAI } \\
\text { SERTA RELASI DENGAN ILMU NAQL } \\
\text { YANG BERKONSEP TIDAK MEMISAHK }\end{array}$ & & $\begin{array}{l}\text { ENGAN KARAKTER \& PENDIDIKAN KARAKTER MANUSIA } \\
\text { ILMU 'AQLIYYAH, ILMU 'AMALIYYAH } \\
\text { TARA ILMU SAINS DAN ILMU AGAMA. }\end{array}$ \\
\hline
\end{tabular}

Sumber diolah dari; Al-Qur'an; Irwanto, Psikologi Umum, Jakarta: Gramedia, 1989; Uichol Kim, Kuo-Shu Yang, KwangKuo Hwang, Indigenous And Cultural Psychology: Understanding Peoples In Context, United States of America: Springer Sains+Business Media Inc., 2006; 3.

\section{METODE PENELITIAN}

Metode penelitian yang digunakan adalah pendekatan kualitatif yang tidak memakai analisis statistika. Data yang dijadikan sebagai sumber data adalah data kualitatif yang terjaga kualitasnya dan berbentuk kata atau kalimat yang berasal dari berbagai karya-karya ilmiah. Pembahasan penelitian dilakukan dengan deskriptif yang menggambarkan, memaparkan, melaporkan secara fakta nyata suatu keadaan, suatu obyek atau suatu peristiwa yang terjadi, serta menyingkapkan fakta yang

Dapat Memberikan Pendidikan Tentang Sikap Hormat dan Bertanggung Jawab), Jakarta: Bumi Aksara, 2012. 
saling berhubungan antar permasalahan penelitian yang dibahas dalam bentuk penulisan disertasi.

Sumber data primer yang digunakan adalah ayat-ayat AlQur'an yang memiliki kesamaan dalam tema pendidikan karakter serta yang sesuai dalam pembahasan disertasi, kemudian ditafsirkan dengan merujuk kepada kitab-kitab tafsir Al-Qur'an dari berbagai latar belakang, kemudian untuk redaksi hadits, penulis mengutamakan pengutipan dari kutub al-tis'ah. Sedangkan sumber data sekunder yang digunakan dalam penelitian ini, berfungsi sebagai bahan referensi penting dan untuk memperluas cakupan wawasan pembahasan permasalahan penelitian. Sumber data sekunder terdiri dari karya-karya penelitian ilmiah terdahulu yang relevan, antara lain berupa bukubuku ilmiah yang membahas kajian tentang pendidikan karakter dalam berbagai sudut pandang/perspektif.

Metode Tafsir Al-Qur'an yang dipakai sebagai metode analisis dalam penelitian disertasi ini adalah Metode Tafsir AlMaudhu'i. ${ }^{28}$ Metode Tafsir Al-Maudhu'i dipilih dalam penelitian ini, dikarenakan metode ini dapat digunakan sebagai penggali permasalahan penelitian dalam upaya menyusun konsep pendidikan karakter indigenous dalam perspektif Al-Qur'an secara lebih komprehensif. Langkah-langkah yang dilakukan dalam memakai metode Tafsir Al-Maudhu'i adalah sebagai berikut $;{ }^{29} 1$ ). Melakukan identifikasi ayat-ayat dalam Al-Qur'an yang berkaitan dengan tema permasalahan penelitian, disesuaikan dengan "term" atau terminology kata yang terkandung dalam

\footnotetext{
${ }^{28}$ Salah satu bentuk tafsir yang dikembangkan para ulama kontemporer adalah tafsir tematik yang dalam bahasa Arab disebut dengan al-Tafsir almaudhu'i, Tafsir ini berupaya menetapkan satu topik tertentu dengan jalan menghimpun seluruh atau sebagian ayat-ayat dari beberpa surah yang berbicara tentang topik tersebut untuk kemudian dikaitkan satu dengan yang lainnya sehingga pada akhirnya diambil kesimpulan menyeluruh tentang masalah tersebut menurut pandangan Al-Qur'an. Lajnah Pentashihan Mushaf Al-Qur'an - Badan Litbang dan Diklat Kementrian Agama, Tafsir al-Qur'an Tematik: Al-Qur'an dan Pemberdayaan kaum Duafa', Jakarta: Aku Bisa, 2012, hal. xix-xx. Abdul Hayy al-Farmawi sebagai mana dikutip Abdul Djalal, mendefinisikan tafsir al-maudhu'i dengan kalimat: "Menghimpun ayatayat al-Qur'an yang mempunyai maksud yang sama dalam arti yang samasama membicarakan satu topik masalah dan menyusunnya berdasarkan kronologis serta sebab turunnya ayat-ayat tersebut, kemudian penafsiran mulai memberikan keterangan dan penjelasan serta mengambil kesimpulan." Abdul Djalal HA, Urgensi Tafsir Maudhu'i pada masa kini, Jakarta: Bulan Bintang, 1991; 84-85.

${ }^{29}$ Rosidin, Metodologi Tafsir Tarbawi, Jakarta: Amzah, 2015; 6-28.
} 
surat dan ayat Al-Qur'an; 2). Mengelompokan ayat-ayat AlQur'an berdasarkan tempat turunnya ayat di Mekkah atau di Madinah, dengan maksud mengetahui frekuensi dan posisi penyebaran "term" yang tersebar di Mekkah atau di Madinah; 3). Menyusun surat dan ayat yang sesuai dengan "term" berdasarkan Asbabun Nuzul surat dan ayat tersebut agar: ${ }^{30}$ a. Memahami kandungan, b. Memperjelas maksud, c. Mengetahui batasanbatasan hukum, d. Menyingkap kesamaran arti yang tersembunyi; 4). Mengetahui munasabah (korelasi/ hubungan) antara suratsurat dan ayat-ayat tersebut dalam Al-Qur'an yang termasuk di dalam "term" penelitian; 5). Melengkapi pembahasan dengan hadits-hadits yang relevan, bersamaan dengan melakukan analisis secara tematik dan menyeluruh berdasarkan "term", serta dengan cara dilihat tafsirnya dan dianalisis Tafsir Al-Qur'an yang berkaitan dengan hal dimaksud.

\section{HASIL PENELITIAN DAN PEMBAHASAN}

Telah disebut sebelumnya bahwa kata "Indigenous" memiliki pengertian sebagai; "Sesuatu yang berakar dari dalam yang masih bersifat bawaan dasar, asli dan alamiah". Sedangkan hasil analisis terhadap karakter indigenous manusia menunjukkan bahwa karakter indigenous manusia perspektif sains adalah karakter alamiah dari sejak dilahirkan yang memiliki sifat berpasangan dan saling berlawanan, yaitu; 1). Karakter Indigenous Kebaikan; 2). Karakter Indigenous Keburukan. Dua jenis karakter indigenous tersebut adalah karakter alamiah yang dapat mengalami perubahan karena adanya suatu pengaruh. Sedangkan yang disebut dengan karakter indigenous perspektif Al-Qur'an adalah karakter alamiah manusia sejak dilahirkan terdiri dari dua jenis karakter yang berpasangan dan saling berlawanan, yakni; 1). Karakter Indigenous Taqwâ (Kebaikan); 2). Karakter Indigenous Fujûr (Keburukan). Sehingga dari dua perspektif dimaksud, maka secara umum dapat dikatakan bahwa karakter indigenous manusia terdiri dua jenis karakter alamiah dari sejak dilahirkan yang bersifat berpasangan dan saling berlawanan, yakni kebaikan dan keburukan. Hal itu dapat diasumsikan berdasarkan pola logika kalimat Ilmu Mantik yang termasuk dalam kondisi qadhiyah syarthiyah munfashilah ${ }^{31}$ dan

\footnotetext{
${ }^{30}$ Manna' Khalil al-Qattan, diterjemahkan oleh Mudzakir, Studi Ilmu-Ilmu Al-Qur'an, Jakarta: Litera AntarNusa, Cet. ke-18, 2015; 108-112.

${ }^{31}$ Qadhiyah Syarthiyah Munfashilah dalam Ilmu Mantik adalah suatu kalimat atau qadhiyah yang muqaddam atau qadhiyah/kalimat pertama dan tali
} 
termasuk ke dalam klasifikasi mani'ah jam'in wa khuluw (haqiqiyah) ijabi. ${ }^{32}$

Kemudian berdasarkan sejarah pendidikan karakter di Indonesia dari sejak tahun 1945 hingga tahun $2019^{33}$, hasil analisis menunjukkan terdapat aspek-aspek karakter yang menjadi intisari dan sangat menonjol disetiap kurikulum dalam proses pendidikan karakter, yakni karakter-karakter; 1). Religius; 2). Cinta Tanah Air; 3). Budi Pekerti. Hal tersebut ditunjukkan dengan adanya 18 karakter bangsa yang harus dididik dan diperkuat untuk seluruh komponen bangsa Indonesia yang sesuai dengan Peraturan Presiden Republik Indonesia No. 87 Tahun 2017, yakni; 1). Religius, 2). Jujur, 3). Toleran, 4). Disiplin, 5). Bekerja keras, 6). Kreatif, 7). Mandiri, 8). Demokratis, 9). Rasa Ingin Tahu, 10). Semangat Kebangsaan, 11). Cinta Tanah Air, 12). Menghargai Prestasi, 13). Komunikatif, 14). Cinta Damai, 15). Gemar Membaca, 16). Peduli Lingkungan, 17). Peduli Sosial, 18). Bertanggung Jawab. ${ }^{34}$

Sehingga jika dipetakan secara keseluruhan berdasarkan uraian dimaksud, maka dapat dikatakan intisari karakter dalam pendidikan karakter adalah; 1). Religius. Karakter religius merupakan karakter yang ditunjukkan oleh sikap dan perilaku yang patuh dalam melaksanakan ajaran agama yang dianutnya, toleran terhadap pelaksanaan ibadah agama lain, dan hidup rukun

atau qadhiyah/kalimat kedua terdapat keterikatan yang berlainan atau berlawanan. Baihaqi A.K., Ilmu Mantik: Teknik Dasar Berpikir Logik, Jakarta: Darul Ulum Press, cet. IV, 2012; 79.

${ }^{32}$ Mani'ah Jam'in wa Khuluw Ijabi dalam Ilmu Mantik adalah suatu bentuk qadhiyah syarthiyah munfashilah yang qadhiyah yang muqaddam atau qadhiyah/kalimat pertama dan tali atau qadhiyah/kalimat kedua tidak mungkin terkumpulkan pada sesuatu sekaligus, tetapi tidak mungkin pula terpisahkan pada sesuatu sekaligus dalam keadaan ijab (positif atau benar). Baihaqi A.K., Ilmu Mantik: Teknik Dasar Berpikir Logik, Jakarta: Darul Ulum Press, cet. IV, 2012; 88-89.

${ }^{33}$ Idrus Alwi dkk., menjelaskannya berdasarkan buku "Lima Puluh Tahun Pendidikan Indonesia" yang diterbitkan oleh Departemen Pendidikan Nasional pada tahun 1996. Dalam Idrus Alwi, Ida Saidah, Umi Nihayah, Panduan Implementasi Kurikulum 2013 Untuk Pendidik dan Tenaga Pendidik, Jakarta: Saraz Publishing, 2014; 1.

${ }^{34}$ Salinan Peraturan Presiden Republik Indonesia No. 87 Tahun 2017 tentang Penguatan Pendidikan Karakter, dalam http://setkab.go.id/inilahmateri-perpres-no-87-tahun-2017-tentang-penguatan-pendidi kan-karakter/, diakses pada tanggal 29/04/2018. 
dengan pemeluk agama lain; ${ }^{35}$ 2). Cinta Tanah Air. Karakter cinta tanah air merupakan karakter yang ditunjukkan dengan cara berfikir, bersikap, dan berbuat yang menunjukkan kesetiaan, kepedulian, dan penghargaan yang tinggi terhadap bahasa, lingkungan fisik, sosial, budaya, ekonomi, dan politik bangsa; ${ }^{36}$ 3). Intelektualitas. Karakter intelektualitas terkait dengan budi pekerti yang berhubungan dengan diri sendiri, orang lain dan lingkungannya. ${ }^{37}$ Karakter intelektualitas dapat dikatakan terdiri dari karakter-karakter (termasuk dalam 18 karakter yang harus diperkuat dalam pendidikan karakter di Indonesia saat ini): Jujur, Toleran, Disiplin, Bekerja keras, Kreatif, Mandiri, Demokratis, Rasa Ingin Tahu, Semangat Kebangsaan, Menghargai Prestasi, Komunikatif, Cinta Damai, Gemar Membaca, Peduli Lingkungan, Peduli Sosial, Bertanggung Jawab.

Perumusan konsep dan model implementasi pendidikan karakter indigenous dalam perspektif Al-Qur'an, terdiri dari; 1). Fokus dari konsep pendidikan karakter indigenous dalam perspektif Al-Qur'an adalah proses mendidik karakter indigenous yang terkait dengan karakter-karakter dalam intisari pendidikan karakter di Indonesia yang telah dijelaskan sebelumnya, yakni intisari karakter: 1). Karakter indigenous religius dalam perspektif Al-Qur'an, terdiri dari; a). Karakter indigenous religius taqwâ (kebaikan) (karakter sesuai dengan ajaran religius); b). Karakter indigenous religius fujûr (keburukan) (karakter berlawanan dengan ajaran religius); 2). Karakter indigenous cinta tanah air dalam perspektif Al-Qur'an, terdiri dari; a). Karakter indigenous cinta tanah air taqwâ (kebaikan) (karakter sesuai dengan kondisi aturan yang berlaku tentang cinta tanah air); b). Karakter indigenous cinta tanah air fujûr (keburukan) (karakter yang berlawanan dengan kondisi aturan yang berlaku tentang cinta tanah air); 3). Karakter indigenous intelektualitas dalam perspektif Al-Qur'an, terdiri dari; a). Karakter indigenous

${ }^{35}$ Said Hamid Hasan dkk., Pengembangan Pendidikan Budaya dan Karakter Bangsa, Jakarta: Badan Penelitian dan Pengembangan Pusat Kurikulum - Kementerian Pendidikan Nasional, 2010; 9-10.

${ }^{36}$ Said Hamid Hasan dkk., Pengembangan Pendidikan Budaya dan Karakter Bangsa, (Jakarta: Badan Penelitian dan Pengembangan Pusat Kurikulum - Kementerian Pendidikan Nasional, 2010), h. 9-10.

${ }^{37}$ Intelektualitas adalah sikap intelektual, berasal dari kata intelektual. Arti kata intelektual adalah: cerdas, berakal, dan berpikiran jernih berdasarkan ilmu pengetahuan Kamus Besar Bahasa Indonesia (KBBI): Kamus Versi On-Line, "Arti kata intelektual", dalam http://kbbi.web.id/intelektual, diakses pada tanggal 10/05/2019. 
intelektualitas taqwâ (kebaikan) (karakter yang sesuai dengan kondisi aturan berlaku berkaitan tentang intelektualitas); b). Karakter indigenous intelektualitas fujûr (keburukan) (karakter yang berlawanan dengan kondisi aturan yang berlaku berkaitan tentang intelektualitas).

Selain itu hasil analisis penelitian ini adalah tersusunnya paradigma yang menjadi acuan di dalam penyusunan konsep pendidikan karakter indigenous dalam perspektif Al-Qur'an ini, yakni; 1). Pendidikan karakter indigenous dalam perspektif AlQur'an adalah konsep dan model implementasi pendidikan karakter yang universal dan tidak ada pemisahan antara ilmu pengetahuan dan teknologi dengan ilmu agama. (Universal and unseparated between transmitted science of God (Naqliyah), theoretical science ('Aqliyyah) and practical science ('Amaliyyah)); 2). Pendidikan karakter indigenous dalam perspektif Al-Qur'an adalah konsep dan model implementasi pendidikan karakter yang didukung surat-surat dan ayat-ayat AlQur'an dalam konteks pendidikan karakter manusia, serta terintegrasi dengan ilmu pengetahuan dan teknologi. (Integrated and supported by Al-Qur'an, science and technology); 3). Pendidikan karakter indigenous dalam perspektif Al-Qur'an adalah konsep dan model implementasi pendidikan karakter yang memberikan fokus pada intisari pendidikan karakter terhadap karakter indigenous Religius, Cinta Tanah Air, Intelektualitas dalam perspektif Al-Qur'an, serta berupaya mengoptimalkan, membangun, mengembangkan karakter indigenous taqwâ (kebaikan) dan berupaya meminimalkan atau menghilangkan karakter indigenous fujûr (keburukan) (To be maximizing taqwâ characters and minimizing fujûr characters); 4). Pendidikan karakter indigenous dalam perspektif Al-Qur'an adalah konsep dan model implementasi pendidikan karakter yang memiliki konsekuensi dari Allah mengenai akibat terhadap pilihan dari masing-masing karakter dimaksud, apakah pilihan kepada karakter indigenous taqwâ (kebaikan) yang akan mendapatkan "reward", maupun pilihan terhadap karakter indigenous fujûr (keburukan) yang akan mendapatkan "punishment". (To be provide understanding of reward and pusnishment on characters choice); 5). Pendidikan karakter indigenous dalam perspektif AlQur'an adalah konsep dan model implementasi pendidikan karakter yang pembahasannya dalam disertasi ini, dibatasi yang dimulai dari sejak masa pranikah, masa prenatal dan masa golden age, sesuai dengan tahapan perkembangan usia dan disesuaikan 
dengan kemampuan maupun kompetensi manusia, serta berdasarkan domain tujuan pendidikan dalam taksonomi pendidikan manusia (implementation for pre-marriage, pre-natal, golden age).

Selain itu, tersusunnya prinsip dan indikator dari konsep pendidikan karakter indigenous dalam perspektif Al-Qur'an yang terbagi dalam 4 bagian; Pondasi, Konten, Penyampaian, Kemampuan. Prinsip dan indikator "Pondasi" terdiri dari; 1). Universal (berlaku umum). Terinspirasi dari QS. AlAnbiyâ'[21];107); 2). Sustainable (berkesinambungan), Terinspirasi dari QS. Alam Nasyrah[94];7; 3). Unbounded (tidak ada batasan). Terinspirasi dari QS. Ali Imran[3];37. Prinsip dan indikator "Konten" terdiri dari; 1). Simplify (memudahkan). Terinspirasi dari QS. Al-A'lâ[87];8; 2). Understandable (mudah dipahami). Terinspirasi dari QS. Al-Qomar[54];17; 3). Similarity (mirip persoalan kehidupan). Terinspirasi dari QS. AlBaqarah[2];55; 4). Multisosiocultural (untuk semua lapisan budaya masyarakat). Terinspirasi dari QS. Al-Hujurât[49];13. Prinsip dan indikator "Penyampaian" terdiri dari; 1). Fun (menyenangkan). Terinspirasi dari QS. "Abasa[80];32; 2). Comfortable (nyaman tidak terpaksa). Terinspirasi dari QS. AlNisâ[4];146; 3). Active (aktif, giat dan bersemangat). Terinspirasi dari QS. Ali Imran[3];104; 4). Togetherness (kebersamaan). Terinspirasi dari QS. Al-Mâidah[5];2. Prinsip dan indikator "Kemampuan" terdiri dari; 1). Knowing (pengetahuan). Terinspirasi dari QS. Yusuf[12];55.; 2). Feeling (perasaan). Terinspirasi dari QS. Al-Ra'd[13];28; 3). Talking (perkataan). Terinspirasi dari QS. Ibrahim[14];24; 4). Doing (perbuatan). Terinspirasi dari QS. Al-Nahl[16];90; 5). Inspiring (menginspirasi). Terinspirasi dari QS. Al-Syams[91];7-10.

Hasil analisis penelitian yang lainnya adalah terungkap adanya karakter indigenous religius, cinta tanah air, intelektualitas dalam perspektif Al-Qur'an dari para Nabi - antara lain; 1). Nabi Adam, kandungan isyaratnya dalam Al-Qur'an dicari berdasarkan term "دم" 2). Nabi Ibrahim, kandungan isyaratnya dalam Al-Qur'an dicari berdasarkan term "إبر اهيخ"; 3 ). Nabi Muhammad, kandungan isyaratnya dalam Al-Qur'an dicari berdasarkan term "محم". - Sebagai salah satu uraian dari hal dimaksud, diantaranya adalah karakter indigenous religius, cinta tanah air, intelektualitas Nabi Adam dalam perspektif Al-Qur'an yakni: 
Karakter indigenous religius taqwâ (kebaikan) Nabi Adam dalam perspektif Al-Qur'an, yakni: 1). Taat kepada Allah (QS; 7/19; 2/35; 3/33), 2). Mau langsung bertaubat mengubah kesalahan (QS; 7/23; 20/122; 2/37), 3). Mengakui ke-Esa-an Allah (Monotheism) (QS; 7/173), 4). Takut kepada Allah (QS; 19/58), 5). Bertaqwa kepada Allah (QS; 4/1), 6). Ikhlas tidak menerima upah dalam tolong menolong sesama (QS; 4/1), 7). Selalu bersilaturahim (QS; 4/1), 8). Berkeyakinan agama Tauhid (QS; 23/52); 9). Pernah tergoda bujuk rayu setan namun segera mengingat Allah dan bertaubat kepada Allah (QS; 7/20-22; 20/117; 20/120; 20/121; 2/36), 10). Pernah lalai/lupa (nasiya) namun segera mengingat Allah dan bertaubat kepada Allah (QS; 20/115). Selain itu Nabi Adam tidak memiliki karakter indigenous religius fujûr (keburukan).

Karakter indigenous cinta tanah air taqwâ (kebaikan) Nabi Adam dalam perspektif Al-Qur'an, yakni: 1). Kepemimpinan (Leadership) (QS; 19/58). Selain itu Nabi Adam tidak memiliki karakter indigenous cinta tanah air fujûr (keburukan).

Karakter indigenous intelektualitas taqwâ (kebaikan) Nabi Adam dalam perspektif Al-Qur'an, yakni; 1). Rendah hati (QS; 38/71); 2). Mulia (QS; 38/72-77; 7/11; 7/12; 20/116; $20 / 118 ; 20 / 119 ; 17 / 61 ; 15 / 26 ; 18 / 50 ; 2 / 34) ; 3$ ). Mandiri (QS; $6 / 98 ; 3 / 59 ; 4 / 1)$; 4). Mau belajar (QS; 2/31); 5) . Mau menghafal (QS; 2/31); 6). Mudah mengingat (QS; 2/31); 7). Percaya diri (QS; 2/31); 8). Teliti (QS; 2/33). Selain itu tidak memiliki karakter indigenous intelektualitas fujûr (keburukan).

Kemudian ditemukan juga mengenai karakter indigenous religius, cinta tanah air, intelektualitas taqwâ manusia seperti pada tabel-tabel berikut:

Tabel 4

Karakter Indigenous Religius Taqwâ Manusia ${ }^{38}$

\begin{tabular}{|l|l|l|}
\hline No & \multicolumn{1}{|c|}{$\begin{array}{c}\text { Karakter Indigenous } \\
\text { Religius Taqwâa } \\
\text { (Kebaikan) Manusia }\end{array}$} & Sumber Surat \& Ayat \\
\hline 1 & Taat/Submisif & $8 / 46 ; 2 / 21 ; 1 / 5$ \\
\hline 2 & Sabar & $8 / 66$ \\
\hline
\end{tabular}

${ }^{38}$ Karakter-karakter yang dikelompokan oleh Febriani sebagai "karakter maskulin positif dan feminin positif" manusia. Dalam Nur Afiyah Febriani, Ekologi Berwawasan Gender Dalam Perspektif Al-Qur'an, Jakarta: Mizan, Cet. I, 2014; 167-168. 


\begin{tabular}{|l|l|l|}
\hline 3 & Empati & $33 / 29$ \\
\hline 4 & Pemurah & $57 / 18$ \\
\hline 5 & Tawakal & $12 / 67 ; 14 / 12 ; 39 / 38 ;$ \\
& & $3 / 159$ \\
\hline \multirow{2}{*}{6} & Taqwa (rasa takut) & $2 / 177 ; 8 / 34 ; 13 / 35 ;$ \\
& & $25 / 15 ; 39 / 33 ; 47 / 15$ \\
\hline 7 & Senang memberi & $2 / 3$ \\
\hline 8 & \multirow{2}{*}{ Ikhlash } & $12 / 24 ; 15 / 40 ; 37 / 40 ;$ \\
\hline 9 & Selalu memohon ampun & $37 / 74$ \\
\hline 10 & Bersyukur & $86 / 3$ \\
\hline 11 & Menerima saran/bijak & $2 / 206$ \\
\hline 12 & Pemaaf & $3 / 159$ \\
\hline 13 & Egaliter & $49 / 13$ \\
\hline 14 & Tenang & $33 / 35 ; 66 / 5 ; 89 / 27$ \\
\hline
\end{tabular}

Tabel 5

Karakter Indigenous Cinta Tanah Air Taqwâ Manusia ${ }^{39}$

\begin{tabular}{|l|l|l|}
\hline No & \multicolumn{1}{|c|}{$\begin{array}{c}\text { Karakter Indigenous } \\
\text { Cinta Tanah Air Taqwâa } \\
\text { (Kebaikan) Manusia }\end{array}$} & $\begin{array}{c}\text { Sumber Surat \& } \\
\text { Ayat }\end{array}$ \\
\hline 1 & Konsisten & $8 / 45$ \\
\hline 2 & Mendunia & $17 / 70 ; 49 / 13$ \\
\hline 3 & Kompetitif & $18 / 30$ \\
\hline 4 & Aktif (mujaahidin) & $4 / 95 ; 47 / 31$ \\
\hline 5 & $\begin{array}{l}\text { Obyektif - orang-orang yang adil } \\
\text { (muqsitiin) }\end{array}$ & $5 / 42 ; 49 / 9 ; 60 / 8$ \\
\hline 6 & $\begin{array}{l}\text { Obyektif - orang-orang yang benar } \\
\text { (saadiquun) }\end{array}$ & $49 / 15 ; 14 / 17$ \\
\hline 7 & $\begin{array}{l}\text { Logis (ya' 'qiluun) } \\
8\end{array}$ & $\begin{array}{l}2 / 164 ; 13 / 4 ; 16 / 12 ; \\
\text { Independen }\end{array}$ \\
\hline 9 & Komunikatif & $8 / 53$ \\
\hline 10 & Keseimbangan rasio dan rasa & $3 / 159$ \\
\hline 11 & Kemampuan memimpin & $27 / 9 ; 49 / 10$ \\
\hline 12 & $\begin{array}{l}\text { Lebih merdeka / membela diri } \\
\text { (yantasyiruun) }\end{array}$ & $42 / 39$ \\
\hline
\end{tabular}

${ }^{39}$ Karakter-karakter yang dikelompokan oleh Febriani sebagai "karakter maskulin positif dan feminin positif" manusia. Dalam Nur Afiyah Febriani, Ekologi Berwawasan Gender Dalam Perspektif Al-Qur'an, Jakarta: Mizan, Cet. I, 2014; 167-168. 
Pendidikan Karakțer Indigenous... |

\begin{tabular}{|l|l|l|}
\hline 13 & Lebih bebas bicara & $55 / 3 ; 55 / 4$ \\
\hline 14 & Visioner & $3 / 104$ \\
\hline 15 & Responsif & $3 / 114$ \\
\hline 16 & Progressif & $17 / 36$ \\
\hline 17 & Produktif & $16 / 97$ \\
\hline 18 & Sabar & $8 / 66$ \\
\hline 19 & Empati & $33 / 29$ \\
\hline 20 & Pemurah & $57 / 18$ \\
\hline 21 & Senang memberi & $2 / 3$ \\
\hline 22 & Ikhlash & $12 / 24 ; 15 / 40 ; 37 / 40 ;$ \\
\hline 23 & Bersyukur & $37 / 74$ \\
\hline 24 & Menerima saran/bijak & $86 / 3$ \\
\hline 25 & Pemaaf & $2 / 206$ \\
\hline 26 & Egaliter & $3 / 159$ \\
\hline 27 & Kreatif & $49 / 13$ \\
\hline 28 & Tenang & $13 / 11$ \\
\hline 29 & Koperatif & $33 / 35 ; 66 / 5 ; 89 / 27$ \\
\hline
\end{tabular}

Tabel 6

Karakter Indigenous Intelektualitas Taqwâ Manusia ${ }^{40}$

\begin{tabular}{|c|l|l|}
\hline No & $\begin{array}{c}|c| \\
\text { Karakter Indigenous } \\
\text { Intelektualitas Taqwâ } \\
\text { (Kebaikan) Manusia }\end{array}$ & $\begin{array}{c}\text { Sumber Surat \& } \\
\text { Ayat }\end{array}$ \\
\hline 1 & Konsisten & $8 / 45$ \\
\hline 2 & Mendunia & $17 / 70 ; 49 / 13$ \\
\hline 3 & Kompetitif & $18 / 30$ \\
\hline 4 & Aktif (mujaahidin) & $4 / 95 ; 47 / 31$ \\
\hline 5 & $\begin{array}{l}\text { Obyektif - orang-orang yang adil } \\
\text { (muqsitiin) }\end{array}$ & $5 / 42 ; 49 / 9 ; 60 / 8$ \\
\hline 6 & $\begin{array}{l}\text { Obyektif - orang-orang yang benar } \\
\text { (saadiquun) }\end{array}$ & $49 / 15 ; 14 / 17$ \\
\hline 7 & Logis (ya'qiluun) & $2 / 164 ; 13 / 4 ; 16 / 12 ;$ \\
\hline 8 & Independen & $8 / 53$ \\
\hline 9 & Petualang (intasyara) & $62 / 9$ \\
\hline 10 & Komunikatif & $3 / 159$ \\
\hline
\end{tabular}

${ }^{40}$ Karakter-karakter yang dikelompokan oleh Febriani sebagai "karakter maskulin positif dan feminin positif" manusia. Dalam Nur Afiyah Febriani, Ekologi Berwawasan Gender Dalam Perspektif Al-Qur'an, (Jakarta: Mizan, Cet. I, 2014; 167-168. 


\begin{tabular}{|l|l|l|}
\hline 11 & Keseimbangan rasio dan rasa & $49 / 9 ; 49 / 10$ \\
\hline 12 & Kemampuan memimpin & $27 / 23$ \\
\hline 13 & $\begin{array}{l}\text { Lebih merdeka / membela diri } \\
\text { (yantasyiruun) }\end{array}$ & $42 / 39$ \\
\hline 14 & Lebih bebas bicara & $55 / 3 ; 55 / 4$ \\
\hline 15 & Visioner & $3 / 104$ \\
\hline 16 & Responsif & $3 / 114$ \\
\hline 17 & Progressif & $17 / 36$ \\
\hline 18 & Produktif & $16 / 97$ \\
\hline 19 & Sabar & $8 / 66$ \\
\hline 20 & Empati & $33 / 29$ \\
\hline 21 & Pemurah & $57 / 18$ \\
\hline 22 & Senang memberi & $2 / 3$ \\
\hline 23 & Ikhlash & $12 / 24 ; 15 / 40 ; 37 / 40 ;$ \\
\hline 24 & Bersyukur & $37 / 74$ \\
\hline 25 & Menerima saran/bijak & $86 / 3$ \\
\hline 26 & Pemaaf & $2 / 206$ \\
\hline 27 & Egaliter & $3 / 159$ \\
\hline 28 & Kreatif & $49 / 13$ \\
\hline 29 & Tenang & $13 / 11$ \\
\hline 30 & Koperatif & $33 / 35 ; 66 / 5 ; 89 / 27$ \\
\hline & & $3 / 103$ \\
\hline
\end{tabular}

Untuk karakter indigenous fujûr (keburukan) manusia seperti tabel berikut:

Tabel 7

Karakter Indigenous Fujûr (Keburukan) Manusia ${ }^{41}$

\begin{tabular}{|c|l|l|}
\hline No & \multicolumn{1}{|c|}{$\begin{array}{c}\text { Karakter Indigenous Fujûr } \\
\text { (Keburukan) Manusia }\end{array}$} & Sumber Surat \& Ayat \\
\hline 1 & Arogan (mutakabbirin) & $\begin{array}{l}16 / 69 ; 39 / 60 ; 39 / 72 ; \\
40 / 76\end{array}$ \\
\hline 2 & Aktif dominatif merusak & $2 / 12 ; 2 / 60 ; 7 / 74 ;$ \\
& (mufsidin) & $11 / 85 ; 26 / 183 ; 38 / 28$ \\
\hline 3 & Ekploitatif & $42 / 2$ \\
\hline 4 & Arogan/sombong & $17 / 37 ; 17 / 83$ \\
\hline 5 & Senang membantah & $18 / 45$ \\
\hline
\end{tabular}

${ }^{41}$ Karakter-karakter yang dikelompokan oleh Febriani sebagai "karakter maskulin negatif dan feminin negatif" manusia. Dalam Nur Afiyah Febriani, Ekologi Berwawasan Gender Dalam Perspektif Al-Qur'an, Jakarta: Mizan, Cet. I, 2014; 167-168. 
Pendidikan Karak̦ter Indigenous... |

\begin{tabular}{|c|l|l|}
\hline 6 & Dominatif & $96 / 6 ; 96 / 7$ \\
\hline 7 & Materialistis (world oriented) & $100 / 8$ \\
\hline 8 & Eksessif dalam membangkang & $75 / 5$ \\
\hline 9 & Ambisius & $22 / 51 ; 2 / 217$ \\
\hline 10 & Boros & $17 / 26 ; 17 / 27$ \\
\hline 11 & $\begin{array}{l}\text { Tidak jujur dalam takaran } \\
\text { (mukhsirin) }\end{array}$ & $26 / 181$ \\
\hline 12 & Mencari-cari kesalahan orang lain & $49 / 12$ \\
\hline 13 & Sensitif-egois (yaskatuun) & $9 / 58$ \\
\hline 14 & Reseptif pasif & $2 / 60$ \\
\hline 15 & Lemah & $4 / 28$ \\
\hline 16 & Berkeluh kesah & $70 / 19 ; 70 / 20$ \\
\hline 17 & Sulit mengatasi persoalan & $10 / 19 ; 19 / 37$ \\
\hline 18 & Mudah goyah dalam krisis & $10 / 12$ \\
\hline 19 & $\begin{array}{l}\text { Sulit menyembunyikan emosi } \\
\text { (sedih) }\end{array}$ & $9 / 40 ; 15 / 88 ; 29 / 33$ \\
\hline 20 & Lebih mudah menangis & $19 / 23 ; 19 / 24$ \\
\hline 21 & Kurang independen & $103 / 3$ \\
\hline
\end{tabular}

Sedangkan temuan model implementasi dari konsep pendidikan karakter indigenous dalam perspektif Al-Qur'an, merupakan gabungan dari seperti yang diungkapkan Syafri, ${ }^{42}$ serta dari Abdul Majid dan Dian Andayani dinamakan TADZKIROH ${ }^{43}$ sehingga kolaborasi dari kedua pemikiran dimaksud, disebut dengan TADZKIROH PLUS, yaitu; 1). T: Tunjukkan teladan digabung dengan Qudwah (Keteladanan). Penggabungan model ini untuk membangkitkan sifat alamiah manusia yang lebih suka mencontoh dan meniru suatu perbuatan, serta model qudwah ini lebih universal karena dianggap mampu "berkomunikasi" dengan manusia dari berbagai macam dan tingkat kemampuan intelektualitasnya; 2). A: Arahkan dan berikan bimbingan digabung dengan Al-Amr (Perintah). Penggabungan kedua model ini untuk mengarahkan dan membimbing, serta dibarengi dengan perintah (al-amr) yang bermakna sebagai permintaan melakukan suatu hal yang berhubungan dengan kebaikan; 3). D: Dorongan motivasi digabung dengan Targhîb (Memotivasi). Penggabungan kedua model ini untuk memberi efek motivasi seseorang mengikuti atau

\footnotetext{
${ }^{42}$ Ulil Amri Syafri, Pendidikan Karakter Berbasis Al-Qur'an, Jakarta: Rajawali Pers, 2012; 99-148.

${ }^{43}$ Abdul Majid, Dian Andayani, Pendidikan Karakter Perspektif Islam, Bandung: Remaja Rosdakarya, 2013; 116-117.
} 
melakukan apa yang menjadi tujuan pendidikan; 4). Z: Zakiyah (Niat Murni) digabungkan dengan Kisah. Penggabungan kedua model ini untuk menanamkan niat murni yang bersih dan tulus dengan menguraikan suatu kisah kejadian/cerita tentang suatu hal yang berkaitan dengan niat murni dalam melakukan suatu kebaikan. Dalam Al-Qur'an banyak digunakan model kisah untuk menguraikan suatu kisah atau kejadian yang bekaitan dengan kisah para nabi, atau kisah-kisah dan kejadian-kejadian lainnya; 5). K: Kontinuitas atau terus menerus (sustainable) digabungkan dengan Pembiasaan ('amilus shalihât). Penggabungan kedua model ini untuk mendidikan secara terus menerus melakukan kebiasaan dalam hal kebaikan; 6). I: Ingatkan digabung dengan Tarhîb (Larangan). Penggabungan kedua model ini untuk mengingatkan dan berupaya memberi rasa takut agar meninggalkan atau menjauhi suatu perbuatan/pekerjaan yang bertentangan dengan kebaikan; 7). R: Repetisi, pengulangan digabungkan dengan Pembiasaan ('amilus shalihât). Penggabungan kedua model ini untuk melakukan pembiasaan yang berulang-ulang tentang kebaikan, sehingga semakin lama semakin dimengerti dan dipahami oleh peserta didik; 8). O: Organisasikan kerjasamanya digabungkan dengan Dialog dan Debat. Penggabungan kedua model ini mengajak diskusi dengan dialog dan perdebatan yang terarah, tertib, saling mengharagai antar peserta didik untuk menggali kemampuan berpikir para peserta didik; 9). H: Hati disentuh (touch the heart) digabungkan dengan Kisah. Penggabungan kedua model ini untuk menyentuh hati dengan menguraikan suatu kisah kejadian/cerita tentang suatu hal yang berkaitan dengan kisah mengelola hati.

\section{KESIMPULAN}

Telah terungkap dalam penelitian ini, sesuai dengan tujuan dari penelitian, yakni mengenai; 1). Uraian tentang pengertian indigenous, karakter indigenous; 2). Karakter manusia dalam perspektif sains dan Al-Qur'an dari sejak dilahirkan memiliki 2 jenis karakter indigenous yang berpasangan dan bersifat saling berlawanan, yakni karakter kebaikan (taqwâ) dan karakter keburukan (fujûr); 3). Adanya relasi antara pendidikan karakter indigenous dengan berbagai sains; Ilmu Naqliyah; Ilmu 'Aqliyyah; Ilmu 'Amaliyyah; 4). Terungkap adanya karakter indigenous religius, cinta tanah air, intelektualitas dari Nabi Muhammad ; 5). Terungkap adanya karakter indigenous religius, cinta tanah air, intelektualitas taqwā (kebaikan) manusia; 
6). Terungkap adanya karakter indigenous religius, cinta tanah air, intelektualitas fujūr (keburukan) manusia; 7). Tersusun perumusan model implementasi "TADZKIROH PLUS" di masa usia pranikah, prenatal, serta golden age; 8). Terungkap tentang perumusan konsep pendidikan karakter indigenous dalam perspektif Al-Qur'an, serta model implementasinya untuk masa pranikah, prenatal, golden age.

\section{DAFTAR PUSTAKA}

Al-Qur'an al-Karim.

'Arabi, Muhyi al-Din Ibn (2002), Tafsir Ibn 'Arabi, Beirut: Dar Sadir.

Abidin, Chasiru Zainal (2013), Psikologi Perkembangan, Surabaya: UIN Sunan Ampel.

al-Adawi, Abu Abdullah Musthafa, penerjemah: Ahmad Syaikhu (2015), Shahih al-'ahadits al-Qudsiyah: Shahih Hadits Qudsi, Jakarta: Darul Haq.

Baynes, Renee, Teachers' Attitudes to Including Indigenous Knowledges in the Australian Science Curriculum, The Australian Journal of Indigenous Education; Santa Lucia Vol. 45, Iss. 1, Aug 2016.

Biela, Dorota Kornas (tt.), The paradigm of unity in prenatal education and pedagogy, publisher anynomous, Journal of DOI: 10.2478/v10241-012-0017-3.

al-Birkawi, Syekh Muhammad Pir Ali, edisi Inggris: Syekh Tosun Bayrak al-Jarrahi al-Halwati (ed.) (2015), penerjemah: Ahmad Syamsu Rizal, Dedi Slamet Riyadi, dkk. (ed.), Al-Thariqah al-Muhammadiyah - The Book Of Character - Memandu Anda Membentuk Kepribadian Muslim Secara Autentik, Jakarta: Zaman, 2015.

Bloom, Benyamin S. (1979). Taksonomy of Educational Objectives (The Clasification of Educational Goals) Handbook 1: Cognitive Domain. London : Longman Group Ltd.

Bloom, Benyamin S., Engelhart (1956), The Taxonomy of Educational Objectives The Classification of Educational Goals, Handbook I: Cognitive Domain, New York: David McKay, 1

Covey, Stephen R, The 7 Habits of Highly Effective People (7 Kebiasaan Manusia yang Sangat Efektif), penerjemah: Lyindon Saputra (2013), Pamulang: Binarupa Aksara Publisher. 
Dettmer, Peggy (2006), New Blooms in Established Fields: Four Domains of Learning and Doing. Roeper Review; Journals ProQuest Education Winter; 28, 2.

Devries, Manfred Kets, (2009), Reflections on Character and Leadership, England: Jossey-Bass, cet. 1, 2009.

Faturochman, Wenty, Tabah Aris N. (2017), Memahami Dan Mengembangkan Indigenous Psychology, Yogyakarta: Pustaka Pelajar.

Febriani, Nur Arfiyah (2014), Ekologi Berwawasan Gender Dalam Perspektif Al-Qur'an, Jakarta: Mizan.

Gearing, Brooke Collins, Rosalind Smith, Burning Off: Indigenising the Discipline of English, The Australian Journal of Indigenous Education; Santa Lucia Vol. 45, Iss. 2, Dec 2016.

al-Ghazali, Imam, penerjemah Bahrun Abu Bakar (2014), Ringkasan Ihya Ulumuddin, Bandung: Penerbit Sinar Baru Algensindo.

Goldziher, Ignaz, Mazhab Tafsir dari Aliran Klasik Hingga Modern, edisi terjemahan oleh: M 'Alaika Salamullah, Yogyakarta: el-Saq Press, cet.I, 2003.

Haptonomy Ireland, "What is Haptonomy?", dalam http://www.experience haptonomy.com/haptonomydefinition/, diakses pada tanggal 31/05/2018.

Haptonomy: Bonding The French Way, "What is Haptonomy?", dalam http://haptonomy.co.uk/what-is-haptonomy/, diakses pada tanggal 01/06/2018.

Hasan, Said Hamid (2010), Pengembangan Pendidikan Budaya Karakter Bangsa, Jakarta: Kementerian Pendidikan Nasional, Balibang, Pusat Kurikulum, 2010.

Hidayatullah, M., Furqon, Pendidikan Karakter Membangun Bangsa, Surakarta:Yuma Pustaka, 2010.

Hook, Joshua N., Don E. Davis (2014), Humility, Religion, and Spirituality: Introduction to the Special Issue, JOURNAL OF PSYCHOLOGY \& THEOLOGY, 2014, Vol. 42, No. 1, 3-6 (Copyright 2014 by Rosemead School of Psychology Biola University, 0091-6471/410-730).

Huda, Nur (2016), Konsep Percaya Diri Dalam Al-Qur'an Sebagai Upaya Pembentukan Karakter Bangsa, Jurnal Ilmiah: Inovatif: Volume 2 No. 2 September Tahun 2016.

Hude, M. Darwis, Abd. Muid, N. (ed.) (2015), Logika Al-Qur'an: Pemaknaan Ayat Dalam Berbagai Tema, Jakarta: Eurabia. 
Hunter, James Davison, The Death of Character: Moral Education In Age Without Good Or Evil, New York: Basic Books, 2000.

Istania (2014), Psikologi Dan Kepribadian Manusia Dalam AlQur'an, Jurnal ilmiah: Rasail, Vol.1, No.1.

Jain, Shalini Rupesh (2015), Pigeons, Prayers, and Pollution: Recoding the Amazon Rain Forest in Karen Tei Yamashita's Through the Arc of the Rain Forest, Ariel; Calgary Vol. 47, Iss. 3.

al-Jauziyyah, Ibnu Qayyim, terj. Harianto, Tuhfatul Maudūd bi Ahkāmil Maulūd: Hanya Untukmu Anakku - Panduan Lengkap Pendidikan Anak Sejak Dalam Kandungan Hingga Dewasa, (Kairo: Dār Ibnu Affan, cet. I, 1423H/2003M), Jakarta: Pustaka Imam Asy-Syafi'i, cet.4, 2016.

Kementerian Pendidikan dan Kebudayaan, Peraturan Menteri Pendidikan dan Kebudayaan Republik Indonesia Nomor 84 Tahun 2014 Tentang Pendidikan Anak Usia Dini, Jakarta: Kementerian Pendidikan Kebudayaan, 2015.

Kim, Uichol, Kuo-Shu Yang, Kwang-Kuo Hwang, Contributions to Indigenous and Cultural Psychology: Understanding People in Context, Indigenous And Cultural Psychology: Understanding People In Context, United States of America: Springer Science+Business Media Inc., 2006.

Koesoema, Doni, Strategi Pendidikan Karakter: Revolusi Mental Dalam Lembaga Pendidikan, Jakarta: Kanisius, cet. 1, 2015.

Kumpulan hadits-hadits kutub al-tis'ah (9 Imam: Bukhari, Muslim, Abu Daud, Tirmidzi, Nasa'i, Ibnu Majah, Ahmad, Malik, Darimi) Lidwa Pustaka i-Software - Kitab 9 Imam Hadits, CD-Room.

Lajnah Pentashihan Mushaf Al-Qur'an, Al-Qur'an Tafsir Tematik: Pendidikan, Pembangunan Karakter, Dan Pengembangan Sumber Daya Manusia - Seri 4, Jakarta: Badan Litbang dan Diklat Kementrian Agama RI, Jakarta, 2010.

Lickona, Thomas, Character Matters, New York, Touchstone Rockefeller Center, 2004.

Lickona, Thomas, penerjemah: Juma Abdu Wamaungo (2012), Educating for Character:Mendidik Untuk Membentuk Karakter, Jakarta: Bumi Aksara. 
Majid, Abdul, Dian Andayani (2013), Pendidikan Karakter Perspektif Islam, Bandung: Remaja Rosdakarya.

Marzuki (2015), Pendidikan Karakter Islam, Jakarta: Amzah.

Matthew Krystal (2007), When Tradition Becomes Folklore, The Journal of Latino - Latin American Studies; Omaha Vol. 2, Iss. 3, Spring.

Orbit, Don T. and Jacobs (2003), Way Of The Brave: An Indigenous Perspective On Character Education, Journal International of ProQuest, Vol. 33, Iss. 2.

Prott, Nakashima, D., L. and Bridgewater, P., "Indigenous Knowledge \& Sustainability", dalam http://www.unesco.org/education/tlsf/mods/ theme_c/mod11.html, diakses pada tanggal 17/05/2018.

Purwanto, Agus (2015), Nalar Ayat-Ayat Semesta: Menjadikan Al-Qur'an Sebagai Basis Konstruksi Ilmu Pengetahuan, Bandung: Mizan, cet. 1, 2015.

al-Qahthani, Sa'id bin Ali bin Wahf, penerjemah: Muhammad Muhtadi, Muhammad Albani dkk. (ed.) (2013), al-Hadyu an-Nabawi fi Tarbiyah al-Aulad fi Dhau'Al-Qur'an wa As-Sunnah - Panduan Lengkap Tarbiyatul Aulad, Solo: Zamzam, cet. 1 .

al-Qardhawi, Syekh Yusuf, penerjemah: Amir Hamzah F. dkk.(2015), Ar-Rasul wal Ilmu - Rasulullah \& Science: Ilmu, Belajar \& Pengajaran Dari Sudut Pandang Rasulullah (As-Sunnah), Jakarta: Firdaus.

Rahayu, Warih Jati (2013), Kearifan Lokal Jawa Sebagai Basis Karakter Kepemimpinan, Jurnal Ilmiah Diklus, Edisi XVII, Nomor 01.

Reza, Syah (2014), Konsep Nafs Menurut Ibnu Sina, Jurnal KALIMAH, Vol. 12, No. 2, UNIDA Gontor, September.

Rida, Muhammad Rashid (1999), Tafsir al-Manar, Beirut: Dar al-Kutub al-'Ilmiyyah.

Rosidin (2015), Metodologi Tafsir Tarbawi, Jakarta: Amzah.

Saleh, Akh Muwafik (2012), Membangun Karakter dengan Hati Nurani Pendidikan Karakter untuk Generasi Bangsa, Jakarta: Erlangga.

Samani, Muchlas dan Hariyanto (2012), Konsep dan Model Pendidikan Karakter, Bandung: Remaja Rosdakarya.

Santrock, Jhon W., penerjemah Harya Bimasena (2014), Educational Psychology: Psikologi Pendidikan, Edisi 5, Buku 1, Jakarta: Salemba Empat. 
Shihab, Muhammad Quraish (2000), Menyingkap Tabir Ilahi: Asmaa al Husna Dalam Perspektif Al-Qur'an, Jakarta: Lentera Hati.

Shihab, Muhammad Quraish (2004), Tafsir al-Mishbah, Pesan Kesan dan Keserasian Al-Qur'an, Jakarta: Lentera Hati.

The Economist Intelligence Unit (2012), The Learning Curve: Lesson In Country Performance In Education: 2012 Report, London: Pearson Plc.

The Economist Intelligence Unit (2014), The Learning Curve: Lesson In Country Performance In Education: 2014 Report, London: Pearson Plc.

Ulwan, Abdullah Nashih, penerjemah: Arif Rahman Hakim (2015), Tarbiyatul 'Aulâd fil Islâm: Pendidikan Anak Dalam Islam, Solo: Al-Andalus.

United Nations Educational Scientific and Cultural Organization (UNESCO) (2011), Education For All (EFA) Global Monitoring Report 2011: The Hidden Crisis, Armed Conflict and Education, France: UNESCO.

United Nations: Departement of Economic and Social Affair, "Indigenous Peoples at the UN", dalam https://www.un.org/development/ desa/indigenouspeople/about-us.html, diakses pada tanggal 28/02/2018.

Veldman, Frans (2001), Confirming Affectivity, The Dawn of Human Life The pre-, peri- and postnatal affectiveconfirming, Haptonomic accompaniment of parents and their child, Journal of Neuroendocrinology Letters ISSN 0172-780X Copyright ( $), 2001$.

Wallner, Fritz G., Martin J. Jandl, ed. Uichol Kim, Kuo-Shu Yang, Kwang-Kuo Hwang, The Importance of Constructive Realism for the Indigenous Psychologies Approach - Indigenous And Cultural Psychology: Understanding People In Context, United States of America: Springer Science+Business Media Inc., 2006.

Wibowo, Timothy (2014), Success Begins With Character: Surabaya: pendidikankarakter.com.

Wilcox, Lynn (2018), Criticsm of Islam Psychology: Psikologi Kepribadian-Menyelami Kepribadian Manusia, diterjemahkan oleh Kumalahadi, Yogyakarta: Penerbit IRCiSod. 